\title{
Teachers' Attitude and its Role in the Implementation of Sustainable Inclusive Education
}

\author{
Dina Bethere ${ }^{1}$, Linda Pavitola ${ }^{2 *}$,Svetlana Usca ${ }^{3}$ \\ ${ }^{1,2}$ Liepaja University, Latvia \\ ${ }^{3}$ Rezekne Academy of Technologies, Latvia \\ *linda.pavitola@liepu.lv
}

Article History: Received: 10 November 2020; Revised 12 January 2021; Accepted: 27 January 2021; Published online: 5 April 2021

\begin{abstract}
Education is a public good, a fundamental human right and a basis for guaranteeing the realization of other rights. The study is devoted to the attitude of teachers as one of the factors forming competencies and dispositions and analyses quantitative data related to teachers' subjective assessment towards the inclusion of children with mild to moderate disabilities and their relationship to the provision of sustainable inclusive education. The Technical Manual for Attitudes Towards Teaching All Students Instrument has been used. Its structure has three components: cognitive, affective, and behavioural [1]. For statistical analysis of the research data, the SPSS 25.0 program was used: a method of Descriptive Statistics, Pearson Correlation Test, One - Way ANOVA tests. The study involves teachers from different professional backgrounds. The results confirm disharmony in the structure of teachers' attitudes, revealing a significant deficiency of the cognitive dimension compared to the affective and behavioural dimension.
\end{abstract}

Keywords

Inclusive education; Pupils with special needs; Sustainability; Teacher's attitude

\section{Introduction}

In today's global world, there is now a trend to strengthen and make education more relevant to challenges that the world faces in the social, environmental, and economic spheres both today and in the future. The concept of education system sustainable development is a systematic extension of human rights by opening equal development opportunities for all people nowadays and future generations [2].

People in the global world more and more understand and are aware of the meaning of the concept education for sustainable development and its continuity - it is considered as a lifelong learning process that starts in early childhood and develops and improves throughout education on the primary and secondary level and forth. Besides, the concept includes skills development of technical and vocational character, higher education opportunities, also workplace training and continuous professional skills development, as well as awareness of civic responsibility and social processes. Moreover, the understanding of quality education is much more than the acquisition of basic competencies like literacy and numeracy - it also means value education that creates a basis for developing lifelong values, without which sustainable education and sustainability are unthinkable [3]. In this context, teachers are considered to be as fundamental actors in the education process and possess the strength to affect the whole system to a great extent.

\section{Literature Review}

There are four dimensions that characterize sustainable education, such as sustainability, tenability, health and durability of educational policy and practice [4]. Therefore, the introduction of the principle of inclusion is considered as one of the indicators of the sustainability of education. This is also confirmed by the future perspective.

In this context, the Sustainable Development Goal 4 acknowledges the value of inclusive education and commitment to implement it by the world community - the goal sets the way towards ensuring inclusive and equitable quality education and promoting lifelong learning opportunities for all [5]. The agenda of education, its vision, basic ideas, and principles that are included in Goal 4 can be featured as comprehensive, holistic, universal and with the view to the future. To the great content, it is inspired by a paradigm change in education, believing that education is the means that can transform people's lives, as well as communities and even 
societies, thus effectively addressing and offering possible solutions to both existing and future challenges in the area of national and global education issues. The vision is based on human rights and a humanistic understanding of education and development and follows the principles of social justice, peace, and inclusion. It also values the diversity of all kind - for example, cultural, ethnic, and linguistic and great importance and emphasis are placed on shared responsibility and accountability [5].

In order to implement the above-mentioned vision, teachers are the ones who will largely determine whether the inclusion process will be successful - whether learners will be included or excluded from the supply and process of educational opportunities. To become the initiators and supporters of inclusion, the professional profile of teachers, the competencies to be acquired and expectations, aspirations, as well as their beliefs and norms that dominate teaching practice, need to be seriously considered [3].

The important role of teachers has been restated in the Education 2030 Framework for Action, which foresees to ensure that it is necessary for teachers and educators to be (1) empowered, adequately recruited, well-trained, professionally qualified, motivated, and supported, (2) understood, appreciated, and able to respond to the variety of learners' needs, including the pedagogical, emotional, developmental, and social needs [6].

Research shows that working in the classroom with student diversity is a big challenge. Teachers need both to find various didactic solutions for different groups of students and develop skills to provide individual support, diagnose students' special needs, as well as plan and implement adaptive learning activities [7, 8]. In this regard, not only the professional skills of teachers are important, but also a positive attitude towards their work tasks, interacting partners, job satisfaction, and motivation to perform their professional duties effectively $[9,10]$.

Sustainable inclusive education has been introduced in the Latvian education system for the last twenty years. The analysis of this process confirms that the development of an optimal model of inclusive education is a long and continuous social process, accompanied by political and public discussions, research and the discovery of examples of good practice. One of the most important topics of discussion is the quality and quantity of staff resources needed to provide inclusive education.

This problem is actualized in two national studies commissioned by the Latvian government. One of them points out the need to train teachers on the principles of inclusive education, which, according to international experience, includes not only working with children with special needs but also with other groups at risk of social exclusion and society. Training and support are also needed for educators working with children with disabilities and/or special needs and seeking an individual approach [11]. In its turn, the second emphasizes the increase in the volume of professional development programs for teachers in the field of inclusive education and the special needs of students, as well as aspects of pedagogical ethics [12].

However, along with the process of shaping the country's inclusive education system, higher professional education of teachers is also developing in this direction. At the same time, following regulatory requirements, teachers devote a lot of time to continuing professional development programs. This, in turn, raises the question that opportunities to provide more effective work in an inclusive education environment should be sought not only in improving the quality of teacher education but also in developing a positive attitude that motivates to overcome pedagogical challenges.

The research findings on teachers' attitudes as a basic component in ensuring optimal teaching and learning process have been featured in several publications [13-15]. In this context, an attitude is a state of mind, which can improve or decrease motivation to be more creative, communicate more effectively and produce more effort for the good of pupils and educational institutions.

\section{Methodology}

The purpose is to study the teachers' subjective self-assessment of attitudes towards the implementation of the inclusive education in the context of a three-dimensional model, which includes both the affective perception assertions of the inclusion process and the reactive, behavioural, and cognitive indicators of attitude.

The research questions are: (1) Which components present teachers' attitudes towards inclusive education? and (2) How components of attitudes affect the sustainability of inclusive education?

For data acquisition Jess L. Gregory \& Lori A. Noto survey "Attitudes Towards Teaching All Students" was used [1]. According to the data analysis methodology of the questionnaire, three subscales and their characteristic statements were considered:

Subscale 1 - Belief that all students can succeed in general education classrooms:

- Statement 1: Most of all separate classrooms that exclusively serve students with mild to moderate disabilities should be eliminated;

- Statement 2: Students with mild to moderate disabilities should be taught in regular classes with nondisabled students because they will not require too much of the teacher's time;

- Statement 3: Students with mild to moderate disabilities can be more effectively educated in regular classrooms as opposed to special education classrooms. 
Subscale 2 - Development of personal and professional relationships:

- Statement 1: I would like to be mentored by a teacher who models effective instruction;

- Statement 2: I want to emulate teachers who know how to design appropriate academic interventions;

- Statement 3: I believe including students with disabilities in the regular education classrooms are effective because they can learn the social skills necessary for success.

Subscale 3 - Creation of an accepting environment for all students to learn:

- Statement 1: I would like people to think that I can create a welcoming classroom environment for students with mild to moderate disabilities;

- Statement 2: Students with mild to moderate disabilities can be trusted with responsibilities in the classroom;

- Statement 3: All students with mild to moderate disabilities should be educated in regular classrooms with non-handicapped peers to the fullest extent possible.

Data were coded using the Likert scale, where 1 - strongly disagree, 2 - disagree, 3 - partially disagree, 4 neither agree nor disagree (neutral attitude), 5 - partially agree, 6 - disagree, 7 - strongly agree.

SPSS 25.0 is used for data analysis: Descriptive Statistics, Pearson Correlation Test, Independent - Sample TTest, One - Way ANOVA test. The ANOVA test was used to determine statistically significant differences between the subscales depending on the profile of the respondents (qualifications, experience, etc.). This approach presents difficulties of interpretation, so it is desirable to use the MANOVA test in the future to maximize the differences between the groups of independent variables and form two or more dependent variables. This would make it possible to identify how the synergy between profile data affects self-assessment. The obtained results would facilitate the planning of future professional education events for teachers.

The Cronbach's alpha coefficient $(\alpha=.759)$ calculated for the internal consistency test of the data and between the subscales $(\alpha=.777)$ also indicates good internal consistency.

\section{Data Analysis}

The respondents were selected by purposeful random sampling strategy. In the process of implementation of the ATTAS-mm instrument, there were handed out and received 276 questionnaires.

The dominant participants in the study are subject teachers $-51.4 \%$. The group of respondents also includes primary education teachers $-26.4 \%$, support staff, i.e. speech therapists, special education teachers, educational psychologists, social educators - $4.7 \%$, other representatives of professional groups involved in the implementation of the educational process, i.e. pre-school education teachers, non-formal education teachers, representatives of school administration, regional education policy planners - $9.8 \%$.

Most respondents are women $-87.7 \%$, which reflects the real distribution by gender of teachers in Latvian schools.

Depending on the indicators of the acquired education, $46.7 \%$ of the respondents have a master's degree, $45.3 \%$ - a bachelor's degree, $1.9 \%$ - a doctor's degree, $4.0 \%$ - have another education, but $1.4 \%$ of the respondents have not answered the question about the acquired education.

In connection with work experience in the education system, the majority of respondents have 20 or more years of service $-48.2 \%$, from 15 to 19 years $-14.1 \%$, from 10 to 14 years $-14.5 \%$, from 5 to 9 years $-9.8 \%$, up to 4 years $-13.0 \%$ of respondents.

When answering the question on obtaining a professional qualification for pedagogical work with children with special needs, $43.8 \%$ of respondents indicate that they obtained it only in further education courses, $22.5 \%$ - in higher education, $17.4 \%$ - only in practical work, $14.5 \%$ - indicate various opportunities of professional qualification combinations.

The research data confirm that the respondents have different workloads for working with children with special needs: minimal (up to 1 hour per month) is $7.6 \%$ of respondents, small (2-10 hours per month) - 18.5\%, relatively large (11-80 hours per month) - $29.7 \%$, large (more than 80 hours per month) - 17.4\%. In turn, $24.6 \%$ of respondents indicate that they do not currently provide education for children with special needs.

Regarding plans, $23.9 \%$ of respondents plan to continue working in an educational institution for less than 5 years, $45.7 \%$ of respondents - for 5-10 years, $22.1 \%$ of respondents - for $11-20$ years, $6.5 \%$ - for more than 20 years, $1.8 \%$ of respondents have not answered this question. Respectively, $8.7 \%$ of respondents would like to become the head of an educational institution.

Depending on the location of the educational institution, $58.7 \%$ of respondents work in urban educational institutions, $28.3 \%$ - in rural educational institutions, but $12.0 \%$ - the place of work is between urban and rural areas. Respectively, $43.1 \%$ of respondents work in primary school-type institutions, $44.6 \%$ - in secondary schools, but $12.3 \%$ of respondents, in this case, indicate another option, i.e. pre-school educational institutions, regional education authorities or non-formal education centres.

Evaluating the material provision of educational institutions for the implementation of inclusive education, $48.6 \%$ of respondents consider it insufficient, $43.1 \%$ - sufficient, $4.3 \%$ - very good, because it allows flexible 
improvement of the educational process, but $2.9 \%$ of respondents did not provide an answer to this question.

\section{Results}

In the development of the study, using the Descriptive Statistics test, the mean values of the subscales and their characteristic statements have been determined (see Table 1).

Table 1. Mean values of subscales

\begin{tabular}{lc}
\hline \multicolumn{1}{c}{ Subscale } & Mean \\
\hline $\begin{array}{l}\text { Subscale1 Belief that all students can } \\
\text { succeed in general education classrooms }\end{array}$ & 2.94 \\
$\begin{array}{l}\text { Subscale2 Development of personal and } \\
\text { professional relationships }\end{array}$ & 5.54 \\
$\begin{array}{l}\text { Subscale3 Creation of an accepting } \\
\text { environment for all students to learn }\end{array}$ & 5.26 \\
\hline
\end{tabular}

The results of the Pearson correlation test show the interrelationships between subscale 1 and subscale 2 (see Table 2).

Table 2. Interrelation indicators between subscales

\begin{tabular}{ll|c|c}
\hline Subscales & & Subscale2 & Subscale3 \\
\hline \multirow{2}{*}{ Subscale1 } & $\begin{array}{l}\text { Pearson } \\
\text { Correlation }\end{array}$ & $.327^{* *}$ & $.395^{* *}$ \\
\cline { 2 - 4 } & Sig. (2-tailed) & .000 & .000 \\
\hline \multirow{2}{*}{ Subscale 2 } & $\begin{array}{l}\text { Pearson } \\
\text { Correlation }\end{array}$ & 1 & $.460^{* *}$ \\
\cline { 2 - 4 } & Sig. (2-tailed) & & .000 \\
\hline
\end{tabular}

It should be noted that no correlations were found with the demographics of the respondents in the assessment of the subscale Belief that all students can succeed in general education classrooms. Correspondingly, there are correlations of the sub-scale Development of personal and professional relationships with the respondents' experience $(\mathrm{r}=-.158, \mathrm{p}=.009)$ and job location $(\mathrm{r}=.174, \mathrm{p}=.004)$. In turn, the sub-scale Creation of an accepting environment for all students to learn indicators has an identifiable correlation with the indicators for the period in which the respondents plan to work in an educational institution $(\mathrm{r}=-.129, \mathrm{p}=.032)$.

Using the Independent-Sample T-Test and the One-Way ANOVA test, statistically significant differences were found in the assessments of the statements characterizing the subscales depending on the demographic indicators of the respondents.

The assessments of the subscale Belief that all students can succeed in general education classrooms (subscale 1) show statistically significant differences depending on the type of acquisition of respondents' professional qualifications and respondents' workload (see Table 3).

Table 3. Indicators of statistical differences in the statements characterizing subscale 1

\begin{tabular}{lccc}
\hline $\begin{array}{l}\text { Characteristics } \\
\text { of respondents }\end{array}$ & $\begin{array}{l}\text { Statement } \\
\mathbf{1}^{*}\end{array}$ & $\begin{array}{l}\text { Statement } \\
\mathbf{2}^{* *}\end{array}$ & $\begin{array}{l}\text { Statement } \\
\mathbf{3}^{* * *}\end{array}$ \\
\hline $\begin{array}{l}\text { Type of } \\
\text { professional } \\
\text { qualification } \\
\text { acquisition } \\
\text { Workload }\end{array}$ & - & .005 & .001 \\
\hline
\end{tabular}

\footnotetext{
* Most of all separate classrooms that exclusively serve students with mild to moderate disabilities should be eliminated

** Students with mild to moderate disabilities should be taught in regular classes with nondisabled students because they will not require too much of the teacher's time

*** Students with mild to moderate disabilities can be more effectively educated in regular classrooms as opposed to special education classrooms
}

It should be noted that statistically significant differences $(p=.000)$ depending on the workload for working with children with special needs were found in the statement Most or all separate classrooms that exclusively 
serve students with mild to moderate disabilities. The lowest mean value, in this case, is confirmed by respondents with a workload of more than 80 hours per month (Mean 1.19).

The statement Students with mild to moderate disabilities should be taught in regular classes with non-disabled students because they will not require too much of the teacher's time found statistically significant differences (p $=.005)$ depending on the type of acquisition of professional qualifications for pedagogical work with children with special needs: the average value of assessments for those who received education only in practical work (Mean 3.23) and for those who did not indicate the type of education (Mean 3.80), while the lowest for respondents who received education in a higher education institution (Mean 2.27).

In this case, statistically significant differences $(p=.002)$ are observed depending on the amount of workload with children with special needs. The most supportive of the statement (Mean 3.83) are the respondents who have not indicated the amount of workload and those respondents who do not currently provide education for children with special needs (Mean 3.28). The lowest average value is for respondents with a workload of more than 80 hours per month (Mean 2.31).

In turn, in the assessments of the statement Students with mild to moderate disabilities can be more effectively educated in regular classrooms as opposed to special education classrooms, statistically significant differences ( $p=.001$ ) were found depending on the type of acquisition of professional qualification for pedagogical work with children with special needs: mean value of assessments for those who received education only in practical work (Mean 3.96) and the lowest - for respondents who received education in higher education institution (Mean 2.76).

Besides, statistically significant differences $(p=.000)$ were found depending on the amount of workload with children with special needs. The most supportive of the statement (Mean 5.00) are respondents who have not indicated the amount of workload and those respondents who do not currently provide education for children with special needs (Mean 3.79). The lowest average value is for respondents with a workload of more than 80 hours per month (Mean 2.79).

The assessments of the subscale Development of personal and professional relationships (subscale 2) revealed statistically significant differences depending on the respondents' experience, location of the workplace, type of acquisition of the professional qualification, school material provision and the number of years the respondent plans to work in the educational institution (see Table 4).

Table 4. Indicators of statistical differences in the statements characterizing subscale 2

\begin{tabular}{lccc}
\hline $\begin{array}{l}\text { Characteristics } \\
\text { of respondents }\end{array}$ & $\begin{array}{l}\text { Statement } \\
\mathbf{4}^{*}\end{array}$ & $\begin{array}{l}\text { Statement } \\
\mathbf{5}^{* *}\end{array}$ & $\begin{array}{l}\text { Statement } \\
\mathbf{6}^{* * *}\end{array}$ \\
\hline $\begin{array}{l}\text { Professional } \\
\text { experience }\end{array}$ & - & .022 & - \\
$\begin{array}{l}\text { Workplace } \\
\text { location } \\
\text { Type of } \\
\text { professional } \\
\text { qualification }\end{array}$ & - & .004 & - \\
acquisition \\
$\begin{array}{l}\text { Workload } \\
\text { Material } \\
\text { provision of the } \\
\text { educational } \\
\text { institution } \\
\text { The planned } \\
\text { time to } \\
\text { continue } \\
\text { working in the } \\
\text { educational } \\
\text { institution }\end{array}$ & -006 & - & .000 \\
\hline
\end{tabular}

*I would like to be mentored by a teacher who models effective instruction

**I want to emulate teachers who know how to design appropriate academic interventions

***I believe including students with disabilities in the regular education classrooms are effective because they can learn the social skills necessary for success

The analysis of the data confirms that statistically significant differences $(p=.006)$ were found in the evaluations of the statement I would like to be mentored by a teacher who models effective differentiated 
instruction depending on the material and technical provision of the school. In this case, teachers who work in schools with insufficient resources (Mean 6.18) are more likely to receive professional support, while those whose schools are adequately provided are less likely to receive professional support (Mean 5.75).

Statistically significant $(\mathrm{p}=.022)$ differences were found in the evaluations of the statement $I$ want to emulate teachers who know how to design appropriate academic intervention depending on the respondents' experience in the education system: more often respondents with experience up to 4 years agree with the statement (Mean 5.39), less often respondents with work experience 20 and more years (Mean 4.57). There were also statistically significant $(\mathrm{p}=.004)$ differences depending on the location of the respondent's workplace: teachers with a workplace between urban and rural areas are more willing (Mean 5.50), less - urban teachers (Mean 4.62). In this case, statistically significant differences $(\mathrm{p}=.002)$ are found depending on how many years they plan to continue working at school: respondents who plan to work for another 5-10 years (Mean 4.65) or less than 5 years (Mean 4.73) agree less often, more often agree they who plan to work for more than 20 years (Mean 6.11). In turn, statistically significant $(\mathrm{p}=.000)$ differences were found in the assessments of the statement $I$ believe including students with mild/moderate disabilities in the regular education classrooms is effective because they can learn the social skills necessary for success depending on how the respondents obtained a professional qualification for pedagogical work with children with special needs: more positive attitude express those who indicated that the qualification was obtained only in practical work (Mean 5.13), less often agree the respondents who obtained the qualification in higher education (Mean 4.00). Also, statistically significant ( $\mathrm{p}=$ .006) differences were found depending on the amount of workload: respondents with the low workload - 2-10 hours per month agree more often (Mean 5.16), less often - respondents with workload more than 80 hours per month (Mean 4.23).

The assessments of the subscale Creation of an accepting environment for all students to learn (subscale 3) show statistically significant differences depending on the respondents 'education, location of the workplace, type of acquisition of professional qualification and respondents' workload (see Table 5).

Table 5. Indicators of statistical differences in the statements characterizing subscale 3

\begin{tabular}{lccc}
\hline $\begin{array}{l}\text { Characteristics } \\
\text { of respondents }\end{array}$ & $\begin{array}{l}\text { Statement } \\
\mathbf{7 *}\end{array}$ & $\begin{array}{l}\text { Statement } \\
\mathbf{8}^{* *}\end{array}$ & $\begin{array}{l}\text { Statement } \\
\mathbf{9 * * *}\end{array}$ \\
\hline $\begin{array}{l}\text { Education } \\
\text { acquired } \\
\text { Workplace } \\
\text { location } \\
\text { Type of } \\
\text { professional } \\
\text { qualification } \\
\text { acquisition } \\
\text { Workload }\end{array}$ & - & .046 & - \\
\hline
\end{tabular}

* I would like people to think that I can create a welcoming classroom environment for students with mild to moderate disabilities

**Students with mild to moderate disabilities can be trusted with responsibilities in the classroom

*** All students with mild to moderate disabilities should be educated in regular classrooms with nonhandicapped peers to the fullest extent possible

In this context, statistically significant differences $(\mathrm{p}=.046)$ were found in the assessments of the statement $I$ would like people to think that I can create a welcoming classroom environment for students with mild to moderate disabilities depending on the way the professional qualification was obtained: who obtained their professional qualification in higher education (Mean 5.53) are less likely to agree with those who obtained it only in practical work (Mean 4.94), or who did not indicate how the education was obtained (Mean 4.40).

Assessments of the statement Students with mild to moderate disabilities can be trusted with responsibilities in the classroom showed statistically significant differences $(\mathrm{p}=.046)$ depending on the respondents' education: more often agree those who did not indicate the level of education (Mean 6.50) and those who indicated another option (Mean 5.13) but less likely - those with a doctoral degree (Mean 5.13). Statistically significant differences $(\mathrm{p}=.034)$ were also found depending on the workplace location of the respondent: more often agree those working between urban and rural schools (Mean 6.03), less often - those working in urban schools (Mean 5.57). At the same time, statistically significant differences $(\mathrm{p}=.006)$ are found depending on how the professional qualification was obtained: the statement is more often agreed with by respondents who have obtained a professional qualification in higher education (Mean 5.90) or elsewhere (Mean 5.83), less often by those who have obtained it only in the courses of continuous professional development (Mean 4.07). 
Statistically significant differences $(\mathrm{p}=.045)$ were found in the assessments of the statement All students with mild to moderate disabilities should be educated in regular classrooms with nonhandicapped peers to the fullest extent possible depending on how the professional qualification was obtained: the statement is more often agreed by respondents who have acquired a professional qualification only in practical work (Mean 4.15) or only in the courses of continuous professional development (Mean 4.07), less often by respondents who have obtained a professional qualification in higher education (Mean 3.48) or who have not indicated how the education was obtained (Mean 2.60). Statistically significant differences $(\mathrm{p}=.000)$ were also found depending on the workload of respondents: respondents with a workload of more than 80 hours per month are less likely to agree (Mean 3.13), but respondents who do not currently provide education for children with special needs (Mean 4.44) and respondents with a workload of 2-10 hours per hour per month (Mean 4.22) are more likely to agree.

\section{Discussions}

Although the study participants represent regionally diverse schools, the group of respondents generally presents a typical team of professionals involved in the implementation of inclusive education daily. It includes both subject teachers who teach languages, history, social sciences, mathematics, and other subjects for students in different classes. The community of professionals in inclusive schools also includes primary school teachers, support staff and school administration. In some places, schools also implement a pre-school education program to prepare children aged 5-6 to start primary education. Consequently, primary school teachers also belong to the community.

When answering the question about the attitude of teachers towards the indicators presenting inclusive education, the data analysis confirms that the mentioned team of professionals is characterized by a disharmonious structure of the attitude. In this case, there are shortcomings towards the cognitive dimension of attitudes (subscale 1), for example, the idea that all students can succeed in general education classes (see Table $1)$.

Although the mean values of other components of attitude are much higher than those of the cognitive component, its effect can also be observed on the affective component (see Table 2).

The analysis of the scientific literature confirms that the development of teacher attitudes in inclusive settings is also influenced by the various individual and social factors: teachers' life and professional experience, competence, self-esteem, type of educational institution, where the teaching staff is employed, number of children with special needs in the classroom, support of the professional environment, etc. [16-19].

In this case, dominant factors can be identified that influence the attitudes of professionals involved in the implementation of inclusive education. These include the acquired education, the way of obtaining a professional qualification for working with children with special needs, workload and experience in an inclusive education environment, the location of the workplace and its material provision (see Tables 3-5).

In general, the analysis of the data confirms the contradictions with the findings of the international studies that teachers who have more experience of daily professional practice in inclusive education demonstrate a more positive attitude [20]. In this case, a more positive attitude in all its dimensions is identifiable for teachers with work experience up to 4 years or for those respondents who do not currently provide education for children with special needs.

Accordingly, the dominant-negative attitude in all elements of its structure is observed for respondents who are employed in inclusive education for more than 80 hours per month.

In turn, the acquired education has a contradictory value in this case, because a more positive attitude is found in the group of respondents who have gained experience in working with children with special needs only in practical work. However, teachers who have obtained a professional qualification in higher education are more positive about the behavioural component of attitudes.

On the other hand, teachers employed in educational institutions with more limited material provision express a more positive attitude towards being mentored by a teacher who models effective differentiated instruction.

Using the results of data analysis to answer the question about the impact of components of attitudes on the sustainability of inclusive education, it can be seen that respondents who feel the emotional response to their work are ready to take action to achieve positive results, but do not believe in the possibility of this achievement. Besides, increasing negative tendencies of attitude are observed especially for those teachers whose workload and, consequently, the amount of experience in inclusive education is higher. In this regard, returning to the above thesis on sustainable education, which implies a sustained educational policy and practice, it can be assumed that sustainable education is not ensured in practice. 


\section{Conclusions}

Regarding the question of attitudinal components that affect teachers' involvement in inclusive education, there is an identifiable disharmony in the interaction of attitude components. The study involves teachers with different levels of an individual professional career. In the context of the study, the structure of the attitudes of teachers are also influenced by the following factors like acquired education, type of acquisition of professional qualification for work with children with special needs, workload and experience in an inclusive education environment, location of the workplace and its material provision.

Regarding the question of attitudinal factor that affect teachers' involvement in inclusive education, there is an identifiable disharmony in the interaction of attitude components. There are important and statistically significant differences between the subscales and statements. The findings of the study would be helpful to education providers in planning the content of continuous professional development of teachers and organizing groups. The indicators of attitude should also be studied at the level of the educational institution to understand how and what factors influence the structure of attitude and find solutions for its improvement.

This characterization of the attitude development process provides some answers to the question of the components of attitudes needed to be updated in teacher education. Teacher study programs should include both theoretical courses and opportunities for practical action in an inclusive education environment. As a result, providing the future teachers with a sense of personal ability and influence that would preventively serve the competent use of personal physical, mental, and social resources would help to overcome the challenges of inclusive education in a professional career.

\section{Limitations and Future Studies}

The disharmony of the structure of teachers' attitudes limits the opportunities to ensure sustainability in educational practice. To improve the situation, the real interaction of education policy planning, education laws and regulations with the real situation in the education system should be considered. To this end, systematic research into the process of inclusive education would be needed. Also, it needs to focus not only on the identification of existing shortcomings but also on a constructive analysis of examples of good practice.

\section{Acknowledgement}

The authors of the article are very grateful to J. Gregory, Ed.D. Associate Professor in Educational Leadership and Policy Studies at Southern Connecticut State University for the permission to use the ATTAS-mm instrument in the study performed in Latvia.

\section{References}

[1] Gregory, J. L. \& L. A. Noto, L. A. (2012). Technical Manual for Attitudes Towards Teaching All Students (ATTAS-mm) Instrument. Retrieved March 18, 2019, from https://eric.ed.gov/?id=ED537530

[2] Schneidewind, U. (2018). Die Große Transformation. Eine Einführung in die Kunst gesellschaftlichen Wandels. $\quad$ Retrieved June $\quad 10, \quad 2019, \quad$ from https://www.researchgate.net/publication/330074034_Die_Grosse_Transformation_Eine_Einfuhrung_in_d ie_Kunst_gesellschaftlichen_Wandels/link/5c2baf62458515a4c7058b8f/download

[3] UNESCO (2014). UN Decade of Education for Sustainable Development (2005-2014). Final Report. $\begin{array}{llll}\text { Retrieved January } & 11, & 2020, & \text { from }\end{array}$ https://sustainabledevelopment.un.org/content/documents/1682Shaping\%20the\%20future\%20we\%20want. pdf

[4] Sterling, S. (2001). Sustainable Education - Re-Visioning Learning and Change. Schumacher Society Briefing no. 6, Green Books, Dartington.

[5] UNESCO (2016). SDG4 - Education 2030 Framework for Action. Retrieved June 20, 2020, from http://uis.unesco.org/sites/default/files/documents/education-2030-incheon-framework-for-actionimplementation-of-sdg4-2016-en_2.pdf

[6] Opertti, R. (2017). SDG 4- Education 2030 Agenda: A window of opportunity for inclusive education and inclusive teachers. International Conference on Competent Teachers Create Efficient Education. Retrieved May 15, 2020, from http://www.ibe.unesco.org/sites/default/files/resources/ibe_paper_for_gaserc.pdf

[7] Lipowsky, F. \& Lotz, M. (2015). Individualisierung der Königsweg zum Lernen? Eine Auseinandersetzung mit Theorien, Konzepten und empirischen Befunden. In G. Mehlhorn, F. Schulz \& K. Schöppe (Eds.), Begabungen entwickeln \& Kreativität fördern (pp. 155-219). München: Kopaed.

[8] Vock, M. \& Gronostaj A. (2017). Umgang mit Heterogenität in Schule und Unterricht. Bonn: Brandt. 
[9] Brooks, R. \& Goldstein, S. (2007). Das Resilienz-Buch: Wie Eltern ihre Kinder fürs Leben Stärken. Stuttgart: Klett-Cota.

[10] Stangl, W. (2020). Motivation von Lehrern und Lehrerinnen. Werner Stangls Pädagogik News. Retrieved June 20, 2020, from https://paedagogik-news.stangl.eu/motivation-von-lehrern-und-lehrerinnen/

[11] Pètījums par starptautisko praksi personu ar invaliditāti atbalsta sistēmu jomā [Study of the cost model of support services for children with special needs in the context of the implementation of inclusive education] (2017). $\quad$ Retrieved $\quad$ February $\quad 10, \quad 2020, \quad$ from http://www.lm.gov.lv/upload/aktuali/lm_inv_gala_nod.pdf

[12] Pètījums par bērniem ar speciālām vajadzībām sniedzamo atbalsta pakalpojumu izmaksu modeli iekl̦aujošas izglītības īstenošanas kontekstā [Study on international practice in the field of support systems for people with disabilities] (2017). Retrieved June 12, 2019, from http://petijumi.mk.gov.lv/sites/default/files/title_file/IzM_Petijums_par_berniem_ar_spec_vajadz_sniedza mo_atbalsta_paklp_imaksu_modeli.pdf.

[13] Bethere, D., Vecenane, H. \& Usca, S. (2018). Exploring Teachers' Attitude in the Context of Inclusive Education. In ICLEL2018 Conference proceeding book (pp. 342 - 353). ICLEL Publication.

[14] Bethere, D., Pavitola, L. \& Usca, S. (2016). Building Pedagogical Relationships in Diverse Educational Environments. International Journal of Arts \& Sciences (IJAS), 05(1), 263-274.

[15] Bethere, D., Pavitola, L. \& Usca, S. (2019). Interconnections between Teachers' Attitude and Inclusive Education. 10th ICEEPSY 2019 The International Conference on Education \& Educational Psychology. In: The European Proceedings of Social \& Behavioural Sciences (pp. 526-536), EPSBS,

[16] Avramidis, E. \& Norwich, B. (2002). Teachers' attitudes towards integration/inclusion: a review of the literature. European Journal of Special Needs Education, 17(2), 129-147.

[17] Boer. A. A. (2012). Inclusion: a question of attitudes? Retrieved April 20, 2020, from http://www.included.eu/sites/default/files/documents/proefschrift.pdf

[18] Hellmich, F., Görel, G. \& Schwab, S. (2016). Einstellungen und Motivation von Lehramtsstudentinnen und -studenten in Bezug auf den inklusiven Unterricht in der Grundschule. Ein Vergleich zwischen Deutschland und Österreich, Empirische Sonderpädagogik, 1(8), 67-85.

[19] Urton, K., Wilbert, J. \& Hennemann, T. (2014). Der Zusammenhang zwischen der Einstellung zur Integration und der Selbstwirksamkeit von Schulleitungen und deren Kollegien. Empirische Sonderpädagogik, 6(1), 3-16.

[20] Praisner, C. L. (2003). Attitudes of Elementary School Principals toward the Inclusion of Students with Disabilities. Exceptional Children, 69(2), 135-145. 